\title{
ЗМІНИ ПОКАЗНИКІВ БІЛКОВОГО ОБМІНУ В ОРГАНІЗМІ ЩУРІВ ЗА УМОВ СПОЖИВАННЯ ПИТНОЇ ВОДИ 3 ВМІСТОМ НІТРАТІВ ТА СОЛЕЙ ЖОРСТКОСТІ
}

Вступ. 3 питною водою в організм людини надходить багато різних хімічних речовин. $€$ такі, які в понаднормативній кількості можуть негативно вплинути на організм споживачів. До таких речовин належать нітрати або солі азотної кислоти, які надзвичайно поширені у навколишньому середовищі. Крім нітратів, найбільш пріоритетними хімічними сполуками, які визначаються у підземній воді в кількості, що перевищує нормативи, є солі жорсткості.

Мета дослідження - вивчити вплив питної води з нормативним і понаднормативним вмістом нітратів та солей жорсткості в комбінації на рівні 1, 3, 5 і 10 Гдк на білковий обмін в організмі піддослідних тварин за умов підгострого експерименту.

Методи дослідження. Експеримент проводили на 30 білих щурах-самицях, поділених на 5 груп, які відрізнялися між собою за якістю питної води. Тварини контрольної групи споживали воду з міського водогону, щури 1-ї групи - воду з вмістом кальцію та магнію в поєднанні з нітратами на рівні 1 ГДК, 2-ї групи З ГДК, 3-ї групи - 5 ГДК, 4-ї групи - 10 ГДК. Для оцінки білкового обміну в сироватці крові піддослідних тварин визначали рівень загального білка, креатиніну, сечовини й активність аспартат- та аланінамінотрансфераз.

Результати й обговорення. У результаті споживання тваринами протягом 30 днів питної води 3 нормативним і понаднормативним вмістом нітратів та солей жорсткості виявлено зміни рівня окремих біохімічних показників білкового обміну, а саме зростання вмісту загального білка, креатиніну й активності трансаміназ та зменшення кількості сечовини. Зміни були найбільш виражені у тварин 4-ї групи $(p<0,05)$.

Висновок. За умови тривалого споживання такої питної води можна очікувати, що встановлені зміни призведуть до розвитку патологічних процесів та виникнення захворювань в організмі тварин і людей.

КЛЮЧОВІ СЛОВА: питна вода; нітрати; солі жорсткості; загальний білок; креатинін; сечовина; трансамінази.

ВСТУП. 3 питною водою в організм людини надходить багато різних хімічних речовин. Одні з них надзвичайно необхідні для життя і здоров'я, інші - не мають великого значення $[1,2]$. Але $\epsilon$ й такі, які в понаднормативній кількості можуть негативно вплинути на організм споживачів. До таких речовин належать нітрати або солі азотної кислоти, які надзвичайно поширені у навколишньому середовищі. Вода, забруднена нітратами, небезпечна для людей, а особливо для дітей у перші місяці життя. ІІї споживання спричиняє таке тяжке захворювання, як водно-нітратна метгемоглобінемія, впливає на роботу нервової та серцево-судинної систем, розвиток ембріонів, може призвести до виникнення злоякісних пухлин [3-5].

(с) О. В. Лотоцька, М. В. Данчишин, 2021.
Упродовж останніх років зростає нітратне забруднення ґрунтових вод, які широко використовують у сільській місцевості для водопостачання, внаслідок ненормованого застосування в сільському господарстві мінеральних і, особливо, органічних добрив [6]. Ще 25 років тому науковці, які працювали в складі експедиції "Дністер", встановили, що ґрунтові води криниць у придністровських селах Львівщини та Івано-Франківщини значно забруднені нітратами, концентрація яких перевищувалаГДК для питних вод від 1,1 до 9 разів у 16 з 23 досліджених колодязів [7]. Збільшений вміст нітратів міг бути викликаний як використанням у надмірній кількості органічних і неорганічних (амонійних) добрив жителями цих сіл, так і нерегульованими стоками тваринницьких фрерм та локальними 
фекальними забрудненнями. Упродовж багатьох років дана проблема і надалі залишається актуальною в усіх областях Західного регіону України.

У Західному регіоні України, крім нітратів, найбільш пріоритетними хімічними сполуками, які визначаються у підземній воді в кількості, що перевищує нормативи, є солі жорсткості. Дослідження ВООЗ показують, що жорстка вода негативно впливає на органи травлення, суглоби, утворює камені в нирках та жовчовивідних шляхах, викликає передчасне старіння шкіри, лупу, висип, алергічні реакції. Але деякі науковці вважають, що саме вода $є$ додатковим джерелом кальцію для організму. Крім того, кілька епідеміологічних досліджень продемонстрували зв'язок між ризиком розвитку серцево-судинних захворювань, затримкою росту, репродуктивною недостатністю та іншими проблемами зі здоров'ям і жорсткістю питної води [8].

В організмі надзвичайно важливу роль відіграє білковий обмін. Він лежить в основі всіх життєвих процесів та характеризує фрізіологічний стан організму в цілому. Від його стану й інтенсивності залежать інші види метаболізму, такі, як вуглеводний, жировий і мінеральний обмін. Але у доступній нам літературі відсутні дані про вплив нітратів і солей жорсткості при надходженні з питною водою на білковий обмін в організмі водоспоживачів.

Мета дослідження - вивчити вплив питної води 3 нормативним і понаднормативним вмістом нітратів та солей жорсткості в комбінації на рівні 1, 3, 5 і 10 ГДК на білковий обмін в організмі піддослідних тварин за умов підгострого експерименту.

МЕТОДИ ДОСЛІДЖЕННЯ. Дослідження проведено на 30 білих щурах-самицях, яких утримували на стандартному раціоні віварію Тернопільського національного медичного університету імені І. Я. Горбачевського МОЗ України. Піддослідних тварин поділили на 5 груп по 6 щурів у кожній: контрольна група - тварини, які споживали артезіанську питну воду з міського водогону, інші групи - щури, які споживали питну воду з підвищеним вмістом кальцію та магнію в поєднанні з нітратами у розмірі 1 ГДК (1-ша група), 3 ГДК (2-га група), 5 ГДК (3-тя група), 10 ГДК (4-та група). Для створення модельних водних розчинів використовували питну воду з міського водогону, в яку, з урахуванням фонових рівнів солевмісту, додавали мінеральні речовини $\left(\mathrm{NaNO}_{3}, \mathrm{CaCl}_{2}, \mathrm{MgCl}_{2}\right)$. Групи відбирали методом рандомізації. Експерименти проводили відповідно до Європейської конвенції про захист хребетних тварин, що використовуються для дослідних та інших наукових цілей (Страсбург, 1986) [9], норм біомедичної етики і Загальних етичних принципів експериментів на тваринах, ухвалених на Першому національному конгресі з біоетики (Київ, 2001). Щурів виводили з експерименту шляхом кровопускання під тіопенталнатрієвим наркозом через 30 днів від початку досліду.

Вміст загального білка визначали біуретовим методом, концентрацію креатиніну - стандартним кінетичним методом без депротеїнізації, рівень сечовини - колориметричним оротометричним методом. Активність аспартатамінотрансорерази (АсAТ) та аланінамінотранссрерази (АлАТ) визначали на напівавтоматичному біохімічному аналізаторі "Humalyzer 2000" з використанням стандартних наборів фрірми "Human" (Німеччина). Статистичну обробку результатів проводили із застосуванням комп'ютерних програм STATISTICA 7.0 й Excel 2010. Вибір методу статистичного дослідження базувався на правильності розподілу досліджуваних ознак. Подальше попарне порівнювання груп проводили з використанням U-критерію Манна Уїтні при оцінці рівня статистичної значущості $p<0,05[10]$.

РЕЗУЛЬТАТИ Й ОБГОВОРЕННЯ. ОДНИМ ВЗ базових біохімічних показників, що показують стан білкового обміну в організмі, $\epsilon$ рівень загального білка у крові. При визначенні вмісту загального білка у сироватці крові піддослідних тварин виявили його збільшення: на $8 \%$-у 1-й групі, на $10 \%$ - у 2-й, на $13 \%$ - у 3-й. Проте у тварин 4-ї групи, які споживали питну воду 3 кількістю нітратів та солей жорсткості на рівні 10 ГДК, спостерігали достовірне зростання рівня загального білка у сироватці крові на $40 \%$ $(p<0,05)$ порівняно $з$ контрольною (рис. 1).

Отримані дані свідчать про те, що концентрація вищеописаних речовин у питній воді на

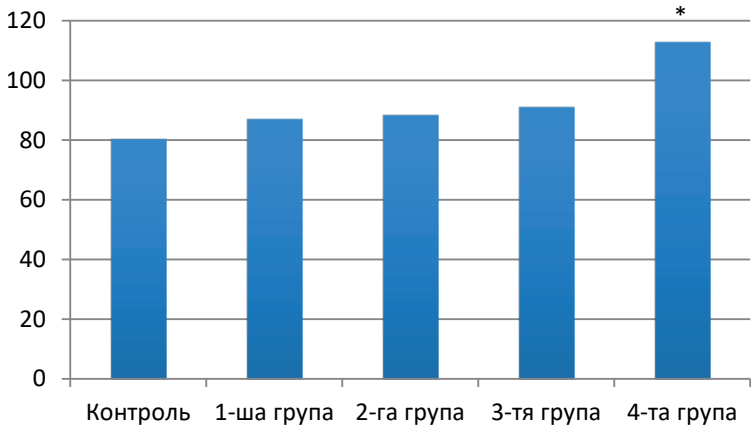

Рис. 1. Рівень загального білка у сироватці крові піддослідних тварин при споживанні питної води з різною концентрацією нітратів та солей жорсткості (г/л).

Примітка. * - тут і далі відмінності достовірні при порівнянні з контрольною групою. 
рівні 1, 3 та 5 ГДК $є$ фрактором малої інтенсивності, а тому не має вираженого токсичного впливу на білковий обмін в організмі тварин. Проте показники у тварин 4-ї групи під дією концентрації солей жорсткості в комбінації з нітратами на рівні 10 ГдК викликають зростання вмісту загального білка, що може вказувати на початок компенсаторних перебудов в організмі щурів. Підвищенню показника сприяють будь-які інфекції, автоімунні хвороби, алергічні реакції, зневоднення, інтоксикація та активний гемоліз, а також наявність злоякісних новоутворень, розвиток яких супроводжується посиленим синтезом і розпадом білкових фрракцій.

Кінцевим продуктом розпаду білків в організмі $\epsilon$ сечовина. Вона утворюється в печінці в результаті цілого каскаду складних біохімічних реакцій. Встановлено, що вміст сечовини у крові піддослідних тварин 1-3 груп був дещо меншим порівняно з контрольною групою - на 14,5, 13,0 та 23,5 \% відповідно. У щурів 4-ї групи показник був достовірно нижчим від контрольних величин - на 37,3 \% (p<0,05) (рис. 2).

Зниження рівня сечовини у крові спостерігають при проблемах з печінкою (печінка зменшує ії синтез), проблемах зі всмоктуванням речовин у процесі травлення та через підвищений синтез білка. Згідно з даними літератури, висока концентрація нітратів у питній воді має негативний вплив на шлунково-кишковий тракт, що, у свою чергу, призводить до змін у роботі печінки та впливає на синтез білка.

Ще одним показником, кінцевим продуктом білкового обміну в організмі теплокровних тварин та людини, є креатинін, що утворюється в процесі дегідратації креатину. При оцінюванні цього показника спостерігали незначну динаміку зростання його вмісту в усіх досліджуваних групах. Найбільше рівень креатиніну підвищився в 4-й групі - на 8,0 \% порівняно з контрольною (рис. 3).

Підвищений вміст креатиніну в крові може вказувати на недостатнє споживання питної води, що, у свою чергу, призводить до зневоднення організму або ниркової недостатності. У тварин 4-ї групи встановлено зростання вмісту креатиніну на фроні зниження рівня сечовини, що могло свідчити про негативний вплив понаднормативної кількості нітратів та солей жорсткості в питній воді, початок патологічних порушень у фрункціонуванні нирок.

Вплив комбінації нітратів і солей жорсткості питної води на фрункцію печінки визначали за активністю у крові окремих ензимів (АсАТ та АлАТ), які беруть активну участь в обміні амінокислот. За активністю ензимів можна скласти уявлення про білковий статус організму. Захво- рювання печінки, які зазвичай супроводжуються ушкодженням гепатоцитів та порушенням їх функціонування, проявляються зростанням активності трансаміназ у крові.

У всіх піддослідних тварин спостерігали підвищення активності АлАТ та АсАТ. У результаті споживання питної води з понаднормативним вмістом нітратів та солей жорсткості на рівні 5 і 10 ГДК статистично достовірно $(p<0,05)$ зростала активність ензиму АлАТ після 1 місяця експерименту в 3-й (на 8,0 \%) та 4-й (на 13,2 \%) групах щурів відносно контрольної (рис. 4).

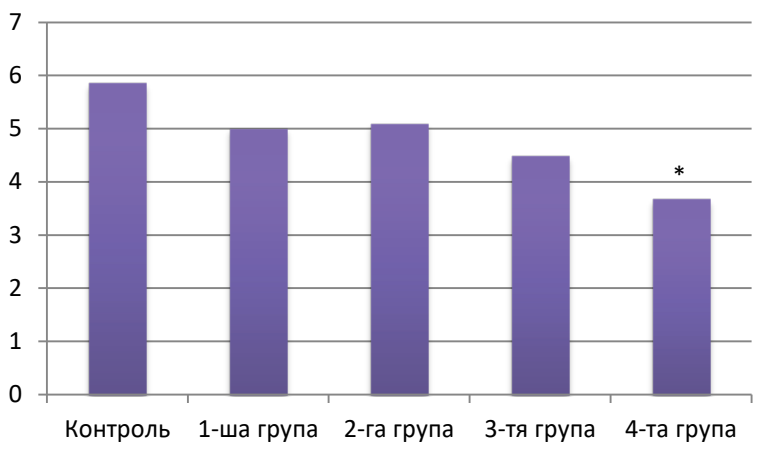

Рис. 2. Рівень сечовини у сироватці крові піддослідних тварин при споживанні питної води з різною концентрацією нітратів та солей жорсткості (ммоль/л).

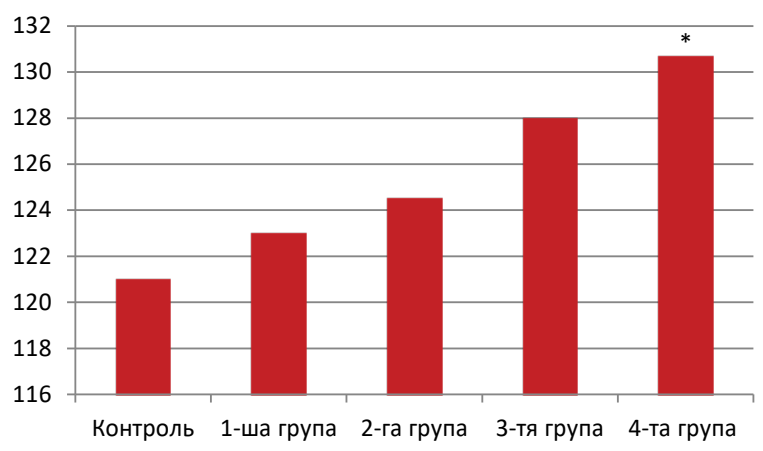

Рис. 3. Рівень креатиніну в сироватці крові піддослідних тварин при споживанні питної води з різною концентрацією нітратів та солей жорсткості (ммоль/л).

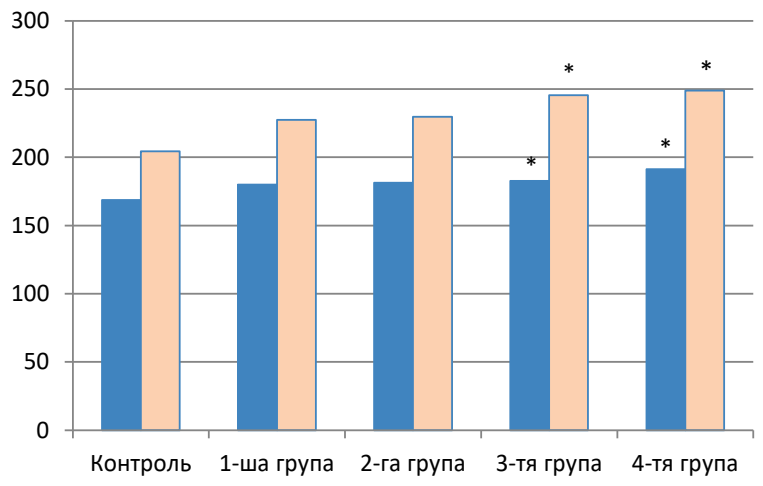

Рис. 4. Активність аланінамінотрансферази й аспартатамінотрансорерази у сироватці крові піддослідних тварин при споживанні питної води з різною концентрацією нітратів та солей жорсткості (ммоль/л). 
У свою чергу, активність АсАТ у сироватці крові щурів під час експерименту зросла дещо більше: на 20,1 \% (p<0,05) - у 3-й групі, на 21,8 \% $(p<0,05)$ - у 4-й порівняно 3 контрольною (див. рис. 4). У тварин 1-ї та 2-ї груп, які споживали питну воду, що містила комбінації солей на рівні 1 та 3 ГДК, не виявлено достовірних змін активності ензимів. Підвищення активності АлАТ та АсАТ у крові, найімовірніше, пов'язане з порушенням структури гепатоцитів, що може бути проявом реакції на приймання змодельованої питної води. Активність цих ензимів у тварин 3-ї та 4-ї груп за умови тривалого споживання некондиційної питної води при проведенні експерименту з часом може зростати, що призводить до розвитку патологічних процесів у печінці й виникнення захворювань.

\section{СПИСОК ЛІТЕРАТУРИ}

1. Мокієнко А. В. Якість води поверхневих водойм як фрактор ризику для здоров'я населення: математична модель / А. В. Мокієнко, Л. Й. Ковальчук, А. Д. Крісілов // Вісн. Національної академії наук України. - 2017. - № 10. - С. 42-52.

2. Прокопов В. О. Вплив мінерального складу питної води на стан здоров'я населення (огляд літератури) / В. О. Прокопов, О. Б. Липовецька // Гігієна населених місць : зб. наук. праць. - К., 2012. Вип. 59. - С. 63-74.

3. Верголяс М. Р. Оцінка токсичності нітратів у воді з використанням цитоморфологічних показників тест-організмів / М. Р. Верголяс // Екологічні науки. 2020. - № 3 (30). - C. 129-132.

4. Drinking water nitrate and human health: An updated review / M. H. Ward, R. R. Jones, J. D. Brender [et al.] // International Journal of Environmental Research and Public Health. - 2018. - 15 (7). - P. 1557. Access mode : https://doi.org/10.3390/ijerph15071557

5. Nitrate and nitrite in drinkingwater:background document fordevelopment of WHO guidelinesfor drinking-
ВИСНОВОК. У результаті споживання тваринами протягом 30 днів питної води з нормативним і понаднормативним вмістом нітратів та солей жорсткості виявлено зміни рівня окремих біохімічних показників білкового обміну, а саме зростання вмісту загального білка, креатиніну й активності трансаміназ та зменшення кількості сечовини. Зміни були найбільш виражені у тварин 4-ї групи ( $<<0,05)$. За умови тривалого споживання такої питної води можна очікувати, що встановлені зміни призведуть до розвитку патологічних процесів та виникнення захворювань в організмі тварин і людей.

Вплив питної води різної якості на стан організму потребує подальших досліджень у майбутньому для профрілактики та попередження розвитку тяжких захворювань.

water quality. Geneva : WHO; 2016. URL : http://www. who.int/water_sanitation_health/dwq/chemicals/ nitratenitrite2ndadd.pdf

6. Лотоцька О. В. Оцінка ризику споживання питної води з підвищеним вмістом нітратів на здоров'я населення Тернопільської області / О. В. Лотоцька, В. О. Прокопов // Довкілля і здоров'я. - 2018. - № 4. C. 21-25.

7. Дослідження Дністра: 10 років громадської екологічної експедиції “Дністер” / ред. М. І. Жарких. Львів ; К., 1998. - 216 с.

8. Sengupta P. Potential health impacts of hard water / P. Sengupta // International Journal of Preventive Medicine. - 2013. - 4 (8). - P. 866-875.

9. European convention for the protection of vertebrate animals used for experimental and other scientific purposes. - Council of Europe, Strasbourg, 1986. - 53 p.

10. Біостатистика: підручник / [В. Ф. Москаленко, О. П. Гульчій, М.В.Голубчиков та ін.] ; за ред. В. Ф. Москаленка. - К. : Книга плюс, 2009. - 184 с.

3. Verholyas, M.R. (2020). Assessment of nitrate toxicity in water using cytomorphological parameters of test organisms. Ecological Sciences, 3 (30), 129-132 [in Ukrainian]

4. Ward, M.H., Jones, R.R., Brender, J.D., de Kok, T.M., Veyyer, P.Dzh., Nolan, B.T., Villanueva, K.M., \& van Breda, S.H. (2018). Drinking water nitrate and human health: An updated review. International Journal of Environmental Research and Public Health, 15 (7), 
1557. Retrieved from: https://doi.org/10.3390/ ijerph15071557

5. (2016). Nitrate and nitrite in drinkingwater: background document fordevelopment of WHO guidelinesfor drinking-water quality. Geneva: WHO. Retrieved from: http://www.who.int/water_sanitation_health/dwq/ chemicals/nitratenitrite2ndadd.pdf

6. Lototska, O.V., \& Prokopov, V.O. (2018). [Risk assessment of drinking water consumption with high nitrate content for the health of the population of Ternopil region]. Environment and Health, 4, $21-25$ [in Ukrainian].
7. Zharkykh, M.I. Ed. (1998). Research of the Dniester: 10 years of the public ecological expedition "Dniester". Lviv, Kyiv [in Ukrainian].

8. Sengupta, P. (2013). Potential health impacts of hard water. International Journal of Preventive Medicine, 4 (8), 866-875.

9. (1986). European convention for the protection of vertebrate animals used for experimental and other scientific purposes. Council of Europe, Strasbourg.

10. Moskalenko, V.F., Hulchiy, O.P., \& Holubchykov, M.V. (Eds.). (2009). Biostatistics: A textbook. Kyiv: Knyha plius [in Ukrainian].

O. V. Lototska, M. V. Danchyshyn
HORBACHEVSKY TERNOPIL NATIONAL

\section{CHANGES IN PROTEIN METABOLISM IN RATS UNDER CONSUMPTION OF DRINKING WATER WITH NITRATES AND HARDNESS SALTS}

\section{Summary}

Introduction. Human body receives many different chemicals with drinking water. But there are those that in excessive quantities can adversely affect the body of consumers. Such substances include nitrates or salts of nitric acid, which are extremely common in the environment. In addition to nitrates, the most preferred chemical compounds, which are determined in groundwater in quantities exceeding the standards, are hardness salts.

The aim of the study - to learn the effect of drinking water with normative and above-standard content of nitrates and hardness salts in combination at the level of 1, 3, 5 and 10 MPC on protein metabolism in experimental animals in the conditions of subacute experiment.

Research Methods. The experiment was performed on 30 white female rats, divided into 5 groups, which differed in drinking water quality. The animals of the control group used water from the city water supply, group 1 water containing calcium and magnesium in combination with nitrates in the amount of 1 MPC, group $2-3$ MPC, group 3-5 MPC, group 4-10 MPC. Serum protein, creatinine, urea, and aspartate aminotransferase and alanine aminotransferase levels were determined in serum to assess protein metabolism in experimental animals.

Results and Discussion. As a result of 30 days of drinking water with normative and excessive content of nitrates and hardness salts revealed changes in the level of certain biochemical parameters of protein metabolism, namely an increase in total protein, creatinine and transaminases and urea. The changes were most pronounced in animals of group $4(p<0.05)$.

Conclusion. Given the long-term consumption of such drinking water, it can be expected that the established changes can lead to the development of pathological processes and the emergence of diseases in animals and humans.

KEY WORDS: drinking water; nitrates; hardness salts; total protein; creatinine; urea; transaminases.

Адреса для листування: М. В. Данчишин, Тернопільський національний медичний університет імені І. Я. Горбачевського мОз України, майдан Волі, 1, Тернопіль, 46001, Україна, e-mail: danchyshyn@tdmu.edu.ua. 